L'ensemble du projet individualise cinq étapes essentielles qui se chevauchent dans le temps : le repérage et l'inventaire des documents cartographiques, leur signalement et leur analyse, leur classement, leur reproduction et enfin la diffusion des résultats obtenus.

Plusieurs analystes documentaires ont pour première tache de consulter, dans les différentes bibliothèques parisiennes, tous les ouvrages relatifs à l'Afrique noire (Madagascar exclue) et les périodiques qui s'y intéressent de façon permanente ou intermittente. Un système de fiches bibliographiques permet de connaître, à tout moment, l'effectif bibliographique dépouillé. Certaines catégories de documents sont délibérément exclues: les cartes d'échelle locale, et les cartes exclusivement topographiques, de repérage ou de nomenclature, les cartes dépourvues d'intérêt scientifique, les cartes publiées avant 1930. Cette première étape est déjà fort avancée (environ 9.000 documents cartographiques ont été repérés et retenus).

Une fiche signalétique, qui rassemble plusieurs ordres de renseignements, est établie dès qu'un document cartographique est retenu. Deux systèmes de pénétration à l'intérieur des 5.000 cartes recensées, deux codes de classement, l'un géographique, l'autre thématique, ont été mis au point, suivant une démarche très empirique. Toutes les cartes seront photographiées (porteuses de leur numéro d'identification) sur microfilms, en noir et blanc ou en couleur, selon le cas.

La diffusion est prévue à deux niveaux. D'une part, l'ensemble des éléments du dossier constitué sont ou seront rassemblés au siège du Centre de Documentation pour l'Afrique Noire (Section Cartographique, 293, Avenue Daumesnil, Paris XIre); d'autre part, une partie des éléments du dossier constitué sera publiée, pour certains probablement à la fin de 1965 (ainsi la liste des documents cartographiques, classés selon le code géographique et le code thématique).

(Abridged from the note by Jean-Paul Gilg and Gérard Remy, in Cahiers d'Études africaines, v. 4, 1965 , pp. 635-7.)

\title{
Graduate-Student Exchange Proposal
}

Professor Henri Le ClercQ, Director of I.R.E.S. of the University of Lovanium (Leopoldville, Congo) would like to hear from any institution which might want to inaugurate a graduate-student exchange programme.

\section{University College, Dar es Salaam: The Library}

Hans Cory collection. The Library possesses the papers of the late Hans Cory, formerly Ethnographer to the Government of Tanganyika. They are mainly concerned with African law and custom. Dr. Norman Miller, from Indiana University, has been sorting the papers, and it is hoped to be able to issue an inventory in the near future.

Mr. Cory also made a collection of clay figurines, which is now in the National Museum, Dar es Salaam. The figurines are very brittle and difficult to handle and it is hoped to photograph them on $35 \mathrm{~mm}$. film.

The Swahili papers of the late Shaban Robert, the Tanzanian author, have been acquired by this Library. A selection is being edited for publication by Mr. John W. T. Allen, at present attached to the Institute of Swahili Research, Box 9184, Dar es Salaam.

The Institute of Swahili Research collection of Swahili manuscripts has been deposited in this Library. At present there are about 250. It is hoped to issue an inventory early in 1966. The Director of the Institute of Swahili Research is Professor Wilfred H. Whiteley.

(Communicated by H. Holdsworth: Librarian) 